\title{
KERAGAAN PEMIJAHAN BUATAN ANTARA IKAN PATIN SIAM (Pangasianodon hypophthalmus) BETINA DAN IKAN PATIN JAMBAL (Pangasius djambal) JANTAN DAN IKAN PATIN NASUTUS (Pangasius nasutus) JANTAN
}

\author{
Bambang Iswanto dan Evi Tahapari \\ Balai Penelitian Pemuliaan Ikan \\ Jl. Raya 2 Sukamandi, Subang 41263 \\ E-mail: bambang.is031@kkp.go.id
}

(Naskah diterima: 23 Agustus 2013; Disetujui publikasi: 25 Juni 2014)

\begin{abstract}
ABSTRAK
Upaya pengembangan budidaya ikan patin jambal (Pangasius djambal) dan ikan patin nasutus ( $P$. nasutus) sebagai komoditas ekspor ikan patin daging putih sulit direalisasikan, karena kematangan induk-induk betinanya sulit dicapai pada musim kemarau dan keterbatasan fekunditasnya, sehingga produksi massal benihnya terbatas. Salah satu upaya yang dapat dilakukan untuk meningkatkan produktivitas ikan patin daging putih adalah melalui program hibridisasi antara ikan patin siam (Pangasianodon hypophthalmus) betina dengan ikan patin jambal jantan (menghasilkan ikan patin hibrida siam $\mathrm{x}$ jambal) dan atau dengan ikan patin nasutus jantan (menghasilkan ikan patin hibrida siam $x$ nasutus). Potensi budidaya kedua ikan patin hibrida tersebut berkaitan dengan produksi massal benihnya merupakan hal yang penting untuk diketahui. Penelitian ini bertujuan untuk mengevaluasi derajat fertilisasi, derajat penetasan, dan derajat deformitas larva kedua ikan patin hibrida tersebut. Hasil penelitian menunjukkan bahwa derajat fertilisasi ikan patin hibrida siam $\mathrm{x}$ nasutus sama $(P>0,05)$ dengan ikan patin siam, ikan patin hibrida siam $x$ jambal dan ikan patin nasutus, sedangkan ikan patin jambal memiliki derajat fertilisasi yang lebih rendah tetapi tidak berbeda $(P>0,05)$ dengan ikan patin nasutus dan ikan patin hibrida siam $x$ jambal. Derajat penetasan ikan patin hibrida siam $x$ nasutus adalah sama $(P>0,05)$ dengan ikan patin siam dan ikan patin hibrida siam $x$ jambal, dan lebih tinggi $(P<0,05)$ daripada ikan patin nasutus dan ikan patin jambal. Derajat deformitas larva ikan patin hibrida siam $x$ nasutus dan ikan patin hibrida siam $x$ jambal rendah dan juga sama dengan ikan patin siam $(P>0,05)$; sedangkan pada ikan patin jambal dan ikan patin nasutus lebih tinggi $(P<0,05)$. Hasil-hasil tersebut menunjukkan bahwa produktivitas (produksi massal benih) kedua ikan patin hibrida tersebut tinggi dan sama dengan ikan patin siam, sehingga potensial untuk dikembangkan sebagai ikan budidaya.
\end{abstract}

KATA KUNCl: fertilisasi, penetasan, deformitas, hibrida, Pangasianodon hypophthalmus, Pangasius djambal, P. nasutus

ABSTRACT: Performances of artificial fertilization between female Pangasianodon hypophthalmus and males of Pangasius nasutus and Pangasius djambal. By: Bambang Iswanto and Evi Tahapari

Attempts to develop the fish culture of both Pangasius djambal and P. nasutus as exported products of white-fleshy pangasiid catfish were difficult to be actualized, since the maturing of female brooders was difficult to be achieved in dry season and their limits in fecundity. Therefore, their continuous mass seed production were restricted. An attempt which could be applied to increase the productivity of white- 
fleshy pangasiid catfish was trough hybridization program between female Pangasianodon hypophthalmus and males of either $\boldsymbol{P}$. djambal (resulted in $\boldsymbol{P}$. hypophthalmus $x$ P. djambal hybrid) or $\boldsymbol{P}$. nasutus (resulted in $\boldsymbol{P}$. hypophthalmus $x$ P. nasutus hybrid). Culture potentialities of both hybrids with regard to their productivity informations in relation to its mass seed production were important things to be elucidated. The present study aimed to evaluate the potency of both hybrids trough evaluation of its fertilization, hatching, and larval deformity rates. The results showed that fertilization rate of $\boldsymbol{P}$. hypophthalmus $x \boldsymbol{P}$. nasutus hybrid was high, and not significantly different $(P>0.05)$ from that of $\boldsymbol{P}$. hypophthalmus, $\boldsymbol{P}$. hypophthalmus $x$ P. djambal hybrid and $\boldsymbol{P}$. nasutus, whereas fertilization rate of $\boldsymbol{P}$. djambal was low, but was not significantly different $(P>0.05)$ from that of $\boldsymbol{P}$. hypophthalmus $x$ P. djambal hybrid and $\boldsymbol{P}$. nasutus. Hatching rate of $\boldsymbol{P}$. hypophthalmus $x$ P. nasutus hybrid was not significantly different $(P>0.05)$ from that of $\boldsymbol{P}$. hypophthalmus and $\boldsymbol{P}$. hypophthalmus $x \boldsymbol{P}$. djambal hybrid, and was higher $(\boldsymbol{P}<0.05)$ than that of $\boldsymbol{P}$. djambal and $\boldsymbol{P}$. nasutus. Larval deformity rate of $\boldsymbol{P}$. hypophthalmus $x$ P. nasutus hybrid and $\boldsymbol{P}$. hypophthalmus $\times$ P. djambal hybrid were not significantly different $(P>0.05)$ from that of $\boldsymbol{P}$. hypophthalmus, and was lower $(P<0.05)$ than those of $\boldsymbol{P}$. djambal and $\boldsymbol{P}$. nasutus. Those overall results suggested that productivity (mass seed production) of both hybrids were high (as well as that of $\boldsymbol{P}$. hypophthalmus), therefore potential to be developed as cultured fishes.

KEYWORDS: fertilization, hatching, deformity, hybrid, Pangasianodon hypophthalmus, Pangasius djambal, P. nasutus

\section{PENDAHULUAN}

Ikan patin merupakan salah satu komoditas unggulan Kementerian Kelautan dan Perikanan (KKP, 2010), terutama sebagai komoditas ekspor ikan patin daging putih. Budidaya ikan patin di Indonesia dimulai sejak introduksi ikan patin siam (Pangasianodon hypophthalmus Sauvage, 1878; sinonim Pangasius hypophthalmus, $P$. sutchi) dari Thailand pada tahun 1972 (Hardjamulia et al., 1981). Ikan patin siam memiliki toleransi yang tinggi terhadap berbagai kondisi kualitas air, fekunditas tinggi, telah terdomestikasi dan dapat dipijahkan sepanjang tahun (Cacot, 1999; Legendre et al., 1999b, 1999c, 2000b; Jalabert, 2008). Kekurangan ikan patin siam adalah warna dagingnya yang kuning, sehingga nilainya sebagai komoditas ekspor relatif rendah (Binh, 2006; Jalabert, 2008).

Indonesia dilaporkan memiliki 14 spesies dari 28 spesies ikan patin yang telah diidentifikasi (Gustiano, 2009). Di antara 14 spesies tersebut, ikan patin jambal (Pangasius djambal Bleeker, 1846), ikan patin nasutus (Pangasius nasutus Bleeker, 1863) dan ikan patin kunyit (Pangasius kunyit; Pouyaud et al., 1999) merupakan spesies yang potensial untuk dikembangkan sebagai komoditas perikanan budidaya (Pouyaud et al., 1999; Legendre et al., 2000a; Legendre, 2008). Ikan patin jambal merupakan spesies ikan patin yang sangat diminati oleh konsumen di Indonesia (Sadili, 1999). Ikan patin jambal berdaging putih sehingga memenuhi standar kualitas ekspor, tetapi fekunditasnya rendah (Sudarto, 1999; Legendre et al., 1999a, 2000a). Demikian pula, ikan patin nasutus merupakan spesies ikan patin daging putih yang bernilai ekonomis penting (Gustiano, 2009), fekunditasnya relatif lebih tinggi daripada ikan patin jambal, tetapi pematangan gonad induk betinanya juga sulit dicapai pada musim kemarau (Tahapari et al., 2008, 2011 ). Dengan demikian, upaya pengembangan budidaya ikan patin jambal dan ikan patin nasutus untuk memenuhi permintaan pasar ekspor ikan patin daging putih sulit direalisasikan karena keterbatasan produktivitasnya (kuantitas dan kontinuitas produksi benihnya).

Salah satu upaya yang dapat dilakukan untuk meningkatkan produktivitas ikan patin daging putih adalah melalui hibridisasi. Hibridisasi merupakan persilangan antara dua spesies ikan yang berbeda karakteristik untuk menghasilkan populasi ikan baru (hibrida) dengan karakteristik yang berupa hasil kombinasi dari kedua induknya (Bartley et al., 2001; Lutz, 2001). Hibridisasi dalam upaya meningkatkan produktivitas dapat dilakukan melalui persilangan antara ikan berfekunditas tinggi dan telah terdomestikasi tetapi memiliki 
kekurangan pada karakter tertentu dengan ikan lain yang memiliki keunggulan pada karakter tertentu tersebut, tetapi produktivitasnya terbatas atau belum terdomestikasi (Chevassus, 1983). Peningkatan produktivitas ikan patin daging putih dapat dilakukan melalui hibridisasi antara ikan patin siam betina dan ikan patin jambal jantan atau ikan patin nasutus jantan. Hal ini dikarenakan ikan patin siam berfekunditas tinggi, telah terdomestikasi, serta dapat dipijahkan sepanjang tahun, sedangkan ikan patin jambal dan ikan patin nasutus berdaging putih. Hibridisasi antara ikan patin siam betina dan ikan patin jambal jantan telah dilakukan dan karakteristik genetis, biometrik, serta pertumbuhannya telah dilaporkan (Ariyanto \& Utami, 2004; Gustiano, 2004; Gustiano \& Kristanto, 2007), sedangkan hibridisasi antara ikan patin siam betina dan ikan patin nasutus jantan masih dalam tahap karakterisasi (evaluasi). Penelitian ini bertujuan untuk mengevaluasi derajat fertilisasi, penetasan, dan deformitas larva ikan patin hibrida hasil hibridisasi antara ikan patin siam betina dan ikan patin jambal jantan (ikan patin hibrida siam $x$ jambal) dan dengan ikan patin nasutus jantan (ikan patin hibrida siam $x$ nasutus) dibandingkan spesies induk-induk tetuanya. Informasi tersebut penting untuk diketahui sebagai salah satu tolok ukur produktivitas berkaitan dengan potensi upaya produksi massal benih ikan patin hibrida tersebut.

\section{BAHAN DAN METODE}

\section{Pemijahan Buatan}

Penelitian ini dilaksanakan di Loka Riset Pemuliaan dan Teknologi Budidaya Perikanan Air Tawar (sekarang Balai Penelitian Pemuliaan Ikan) Sukamandi. Induk ikan patin siam, nasutus, dan jambal yang digunakan pada penelitian ini dipelihara dalam kolam tanah berukuran $200 \mathrm{~m}^{2}$. Pakan yang diberikan berupa pelet komersial dengan kadar protein 28\% (SN, PT Sinta Prima Feedmill, Jakarta), diberikan pada pagi dan sore hari sebanyak 2\% biomassa/hari.

Pemilihan induk betina dilakukan melalui pengambilan sampel telur intraovarian dengan cara kanulasi (intraovarian biopsy) menggunakan kateter khusus (Pipelle de Cornier, Laboratoire C.C.D., Paris, Perancis). Sampel telur intraovarian masing-masing induk betina selanjutnya diamati dan diukur dengan bantuan mikroskop binokuler (Nikon SE, Nikon
China) yang telah dilengkapi mikrometer (KS, Tokyo, Jepang) terkalibrasi pada pembesaran $4 \times 10$. Induk ikan patin siam betina dipilih yang modus diameter telur intraovariannya lebih dari $0,90 \mathrm{~mm}$; lebih dari 1,40 mm untuk ikan patin nasutus, dan lebih dari $1,70 \mathrm{~mm}$ untuk ikan patin jambal, masing-masing sebanyak enam ekor. Induk ikan patin siam, jambal, dan nasutus jantan dipilih yang telah matang gonad, yakni dapat mengeluarkan cairan sperma ketika dilakukan sedikit pengurutan (stripping) pada papila genitalia, masing-masing sebanyak tiga ekor.

Induksi hormonal dilakukan terhadap induk betina dan jantan yang terpilih. Penyuntikan pertama pada induk betina dilakukan menggunakan hormon human chorionic gonadotrophine (CHORULON, Intervet BV, Belanda) dengan dosis $500 \mathrm{IU} / \mathrm{kg}$ induk. Selang 24 jam kemudian, dilanjutkan dengan penyuntikan kombinasi hormon gonadotrophine releasing hormone analogue dan domperidone (ovaprim, Syndel Laboratories Ltd., Canada) dengan dosis $0,6 \mathrm{~mL} / \mathrm{kg}$ induk betina dan $0,2 \mathrm{~mL} / \mathrm{kg}$ induk jantan.

Sperma hasil pengurutan dari induk jantan masing-masing spesies ikan patin (tiga ekor) dicampur dalam satu botol dan diencerkan dengan larutan $\mathrm{NaCl}$ fisiologis 0,9\% (PT Widatra Bhakti, Pandaan, Pasuruan), dengan perbandingan volume sperma dan volume $\mathrm{NaCl}$ fisiologis sebanyak 1:100, kemudian disimpan dalam lemari es (suhu sekitar $4^{\circ} \mathrm{C}$ ). Selanjutnya, dilakukan pengambilan telur melalui pengurutan. Telur dari masing-masing (enam ekor) induk betina tidak dicampur. Fertilisasi dilakukan dengan metode kering (dry method). Aktivasi proses fertilisasi dilakukan menggunakan air mineral (AQUA, PT Tirta Investama, Sukabumi). Telur ikan patin siam difertilisasi dengan sperma ikan patin jambal untuk membentuk ikan patin hibrida siam $x$ jambal dan sperma ikan patin nasutus untuk membentuk ikan patin hibrida siam $x$ nasutus, serta sperma patin siam sendiri. Telur ikan patin jambal dan nasutus hanya difertilisasi dengan sperma masing-masing spesies ikan patin tersebut.

\section{Evaluasi Derajat Fertilisasi, Penetasan, dan Deformitas Larva}

Evaluasi derajat fertilisasi telur pada penelitian ini dilakukan dengan mengacu pada prosedur penelitian evaluasi derajat fertilisasi ikan patin siam (Legendre et al., 2000b) dan 
ikan patin P. bocourti (Cacot et al., 2002; 2003). Penghitungan derajat fertilisasi dilakukan segera pada saat tahap pembelahan sel (morulasi), yakni pada periode waktu sekitar 60-180 menit setelah fertilisasi agar dapat diperoleh hasil derajat fertilisasi yang akurat. Penentuan derajat fertilisasi yang dilakukan selama dalam tahap morulasi tersebut memerlukan pengamatan yang lebih teliti dalam membedakan antara telur yang terfertilisasi dengan telur yang tidak terfertilisasi, karena secara sekilas telur terfertilisasi yang berada pada tahap morula mirip dengan telur yang tidak terfertilisasi (Fuiman, 2002). Hal ini dikarenakan keduanya memiliki bagian sel (blastodisc) dengan ukuran yang relatif sama pada kutub animal, tetapi sebenarnya secara morfologis bentuknya berbeda. Selama periode tahap morulasi, telur terovulasi yang tidak terfertilisasi memiliki bagian sel pada kutub animal yang berupa sel tunggal berukuran besar dengan permukaan yang tampak halus dan tampak masuk ke dalam bagian kuning telur (Gambar 1A), sedangkan telur terfertilisasi yang berada pada tahap morula memiliki banyak sel berukuran kecil-kecil (bergerombol) pada kutub animal sehingga membentuk suatu bagian (massa) yang permukaannya tampak kasar (Gambar 1B). Pengamatan dan penghitungan derajat fertilisasi dilakukan dengan bantuan mikroskop stereo (Nikon SMZ-2B, Nikon, Jepang).

Sebanyak 200-300 butir telur sampel dari masing-masing enam ekor induk betina ikan patin siam, jambal, dan nasutus ditempatkan dalam wadah-wadah plastik kecil tembus cahaya bervolume $300 \mathrm{~mL}$ air mineral (ditempatkan dalam ruang inkubasi dengan suhu air $28^{\circ} \mathrm{C}-29^{\circ} \mathrm{C}$ ). Telur yang tidak terfertilisasi dan tidak mengalami perkembangan (gagal berkembang dan mati) segera dibuang dari media inkubasi.

Derajat fertilisasi $(\mathrm{FR}=$ Fertilization rate $)$ dihitung berdasarkan rumus $\mathrm{FR}=$ (Telur terfertilisasi : Total telur diinkubasi) x 100\% (Cacot et al., 2003). Derajat penetasan (HR = Hatching rate) dihitung berdasarkan rumus $\mathrm{HR}=($ Total larva menetas : Total telur diinkubasi) $\mathrm{x}$ 100\% (Cacot et al., 2003). Derajat deformitas $(\mathrm{DR}=$ Deformity rate) larva dihitung berdasarkan rumus $D R=$ (Jumlah larva mengalami deformitas: Total larva menetas) x 100\% (Legendre et al., 1992). Data derajat fertilisasi, penetasan, dan deformitas larva selanjutnya dianalisis dengan analisis ragam satu arah (one way-analysis of variances) dan jika terdapat perbedaan yang nyata, maka dilanjutkan dengan uji perbandingan berganda (multiple pairwise comparison test) menggunakan uji beda nyata jujur Tukey (Tukey's honestly significant difference) dengan bantuan program komputer (KyPlot 2.0, Koichi Yoshioka, www. qualest.co.jp). Heterosis yang menunjukkan keunggulan keragaan hibrida dibandingkan dengan rata-rata keragaan kedua induk tetuanya (mid-parent heterosis) (Lutz, 2001) juga dihitung $($ Heterosis $=($ Keragaan hibrida Rata-rata keragaan kedua induk tetuanya) : Rata-rata keragaan kedua induk tetuanya $x$ 100\%).
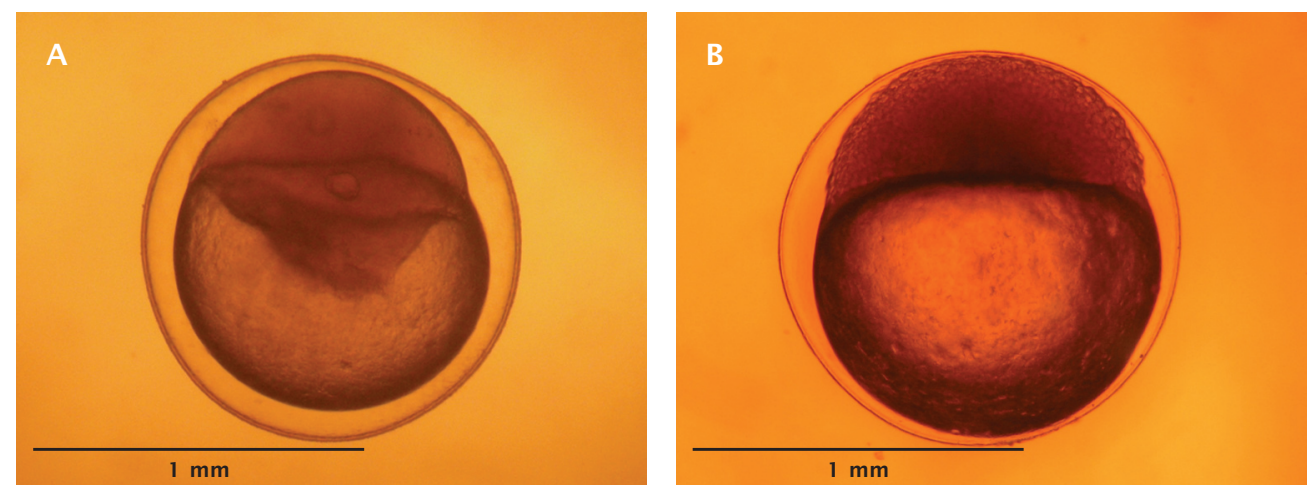

Gambar 1. Telur tidak terfertilisasi dengan sel tunggal berukuran besar yang tampak masuk ke bagian kuning telur (A) dan telur terfertilisasi dengan banyak sel berukuran kecil-kecil (B) pada periode morulasi

Figure 1. Unfertilized egg with single big cell invaded the yolk mass (A) and fertilized egg with multiple small sized cells (B) at morulation stage 


\section{HASIL DAN BAHASAN}

Derajat fertilisasi, penetasan, dan deformitas larva ikan patin siam, jambal, nasutus, patin hibrida siam $x$ jambal, dan patin hibrida siam $x$ nasutus berdasarkan pengamatan terhadap enam kali proses fertilisasi pada penelitian ini disajikan pada Tabel 1. Derajat fertilisasi telur patin siam yang difertilisasi dengan sperma patin nasutus menunjukkan nilai yang sama $(P>0,05)$ dengan derajat fertilisasi ikan patin siam, nasutus, dan patin hibrida siam $x$ jambal. Ikan patin jambal memiliki derajat fertilisasi yang terendah dan berbeda nyata $(P<0,05)$ dengan derajat fertilisasi ikan patin siam dan patin hibrida siam $x$ nasutus, tetapi tidak berbeda nyata $(P>0,05)$ dengan derajat fertilisasi patin nasutus dan patin hibrida siam x jambal.

Hasil tersebut menunjukkan bahwa telur ikan patin siam yang difertilisasi dengan sperma ikan patin jambal dan ikan patin nasutus menghasilkan derajat fertilisasi yang tinggi, dengan heterosis terhadap rata-rata kedua induk tetuanya secara berturut-turut sebesar $1,63 \%$ dan $8,60 \%$ (Tabel 1). Dengan menggunakan telur ikan patin siam yang sama, derajat fertilisasi yang dihasilkan dengan menggunakan sperma ikan patin nasutus relatif lebih tinggi daripada dengan menggunakan sperma ikan patin jambal dan sperma ikan patin siam sendiri. Hal tersebut mengindikasikan bahwa kualitas sperma ikan patin nasutus cenderung lebih bagus dibandingkan sperma ikan patin siam dan ikan patin jambal, dan sesuai (kompatibel) dalam membuahi telur ikan patin siam. Padahal, ikan patin siam dan ikan patin jambal dilaporkan memiliki kualitas sperma yang bagus (LRPTPBAT, 2006; Legendre et al., 2008). Selanjutnya, telur ikan patin nasutus dan jambal yang difertilisasi dengan masingmasing sperma ikan patin nasutus dan jambal menghasilkan derajat fertilisasi yang rendah dengan nilai simpangan baku yang relatif tinggi, mengindikasikan bahwa telur ikan patin nasutus dan jambal yang digunakan dalam penelitian ini lebih rendah dan lebih bervariasi kualitasnya daripada telur ikan patin siam. Padahal, pelaksanaan penelitian ini masih berada pada periode musim penghujan. Halhal tersebut mengindikasikan bahwa telur ikan patin siam dan sperma patin nasutus potensial untuk digunakan dalam proses hibridisasi menghasilkan ikan patin hibrida siam $x$ nasutus dengan tingkat produktivitas yang relatif lebih tinggi daripada menggunakan sperma ikan patin jambal (dalam membentuk patin hibrida siam $x$ jambal). Namun demikian, derajat fertilisasi merupakan evaluasi pada tahap awal dan masih memerlukan evaluasi dan verifikasi lebih lanjut melalui evaluasi derajat penetasan dan deformitas larva.

Derajat fertilisasi pada hibridisasi ikan-ikan Siluriformes (catfish) menunjukkan adanya variasi. Hibridisasi yang menghasilkan derajat fertilisasi relatif tinggi mengindikasikan pada tahap awal bahwa hibridisasi tersebut potensial untuk dikembangkan. Contoh hibridisasi yang menghasilkan derajat fertilisasi tinggi dan potensial untuk dikembangkan antara lain adalah hibridisasi antara ikan patin siam dengan ikan lele C. batrachus dan C. macrocephalus (Tarnchalanukit, 1986), hibridisasi antara ikan lele $C$. batrachus dengan $C$. gariepinus secara resiprokal (Rahman et al., 1995) dan hibridisasi antara betina $H$. longifilis dengan jantan C. gariepinus (Ataguba et al., 2009). Namun demikian, hasil penelitian Lenormand et al. (1999) menunjukkan bahwa derajat fertilisasi hibridisasi antara betina ikan lele $C$. batrachus dengan jantan $C$. gariepinus sangat rendah dibandingkan resiprokalnya, mengindikasikan rendahnya potensi hibridisasi tersebut. Perbedaan hasil penelitian Rahman et al. (1995) dan Lenormand et al. (1999) pada hibridisasi antara ikan lele $C$. batrachus dengan C. gariepinus tersebut dikarenakan identitas spesies ikan lele $C$. batrachus yang digunakan dalam kedua penelitian tersebut sebenarnya berbeda, sebagaimana dilaporkan oleh $\mathrm{Ng} \&$ Kottelat (2008). Haniffa et al. (2009) dalam hibridisasi antara betina ikan Mystus gulio dengan jantan M. montanus menyatakan bahwa hibridisasi tersebut menghasilkan derajat fertilisasi yang lebih rendah dibandingkan induk-induknya, mengindikasikan rendahnya potensi hibridisasi tersebut.

Derajat penetasan telur ikan patin siam yang difertilisasi dengan sperma ikan patin nasutus menunjukkan nilai yang sama $(P>$ $0,05)$ dengan derajat penetasan patin siam dan patin hibrida siam $x$ jambal, dan lebih tinggi $(P<0,05)$ dibandingkan dengan derajat penetasan patin jambal dan patin nasutus. Hasil derajat penetasan tersebut selanjutnya juga menunjukkan bahwa telur ikan patin siam yang sama yang difertilisasi dengan sperma ikan patin nasutus menghasilkan derajat penetasan yang relatif lebih tinggi (dengan heterosis terhadap rata-rata kedua induk tetua- 
Tabel 1. Derajat fertilisasi, penetasan, dan deformitas larva ikan patin siam, jambal, nasutus, patin siam $x$ patin jambal, dan patin siam $x$ patin nasutus, serta heterosisnya

Table 1. Fertilization, hatching, and larval deformity rates of P. hypophthalmus, P. djambal, $P$. nasutus, $\boldsymbol{P}$. hypophthalmus $\times$ P. djambal, and $\boldsymbol{P}$. hypophthalmus $\times$ P. nasutus, including its heterosis

\begin{tabular}{|c|c|c|c|c|}
\hline $\begin{array}{l}\text { Parameter } \\
\text { Parameters }\end{array}$ & $\begin{array}{l}\text { Patin } \\
\text { Pangasiid catfishes }\end{array}$ & $\begin{array}{l}\text { Kisaran } \\
\text { Range }\end{array}$ & $\begin{array}{l}\text { Rataan } \\
\text { Mean }\end{array}$ & $\begin{array}{l}\text { Heterosis } \\
\text { Heterosis }\end{array}$ \\
\hline \multirow{5}{*}{$\begin{array}{l}\text { Derajat } \\
\text { fertilisasi } \\
\text { Fertilization } \\
\text { rate } \\
\text { (\%) }\end{array}$} & $\begin{array}{c}\text { Patin siam } \\
\text { P. hypophthalmus }\end{array}$ & $78.38-98.85$ & $91.44 \pm 8.11^{\mathrm{a}}$ & - \\
\hline & $\begin{array}{l}\text { Patin jambal } \\
\text { P. djambal }\end{array}$ & $40.13-81.08$ & $63.58 \pm 15.33^{b}$ & - \\
\hline & $\begin{array}{l}\text { Patin nasutus } \\
\text { P. nasutus }\end{array}$ & $60.37-96.05$ & $80.23 \pm 13.55^{\mathrm{ab}}$ & - \\
\hline & $\begin{array}{c}\text { Patin siam } \times \text { patin jambal } \\
\text { P. hypophthalmus } \times \text { P. djambal }\end{array}$ & $67.12-89.00$ & $78.77 \pm 8.05^{\mathrm{ab}}$ & 1.63 \\
\hline & $\begin{array}{l}\text { Patin siam } \times \text { patin nasutus } \\
\text { P. hypophthalmus } \times \text { P. nasutus }\end{array}$ & $90.18-97.58$ & $93.22 \pm 3.26^{a}$ & 8.6 \\
\hline \multirow{5}{*}{$\begin{array}{l}\text { Derajat } \\
\text { penetasan } \\
\text { Hatching } \\
\text { rate } \\
\text { (\%) }\end{array}$} & $\begin{array}{l}\text { Patin siam } \\
\text { P. hypophthalmus }\end{array}$ & $64.57-89.93$ & $80.67 \pm 10.32^{a}$ & - \\
\hline & $\begin{array}{l}\text { Patin jambal } \\
\text { P. djambal }\end{array}$ & $24.20-60.36$ & $40.24 \pm 13.72^{c}$ & - \\
\hline & $\begin{array}{l}\text { Patin nasutus } \\
\text { P. nasutus }\end{array}$ & $30.49-79.05$ & $54.37 \pm 19.23^{b c}$ & - \\
\hline & $\begin{array}{l}\text { Patin siam } \times \text { patin jambal } \\
\text { P. hypophthalmus } \times \text { P. djambal }\end{array}$ & $52.54-86.60$ & $70.90 \pm 11.36^{\mathrm{ab}}$ & 17.28 \\
\hline & $\begin{array}{c}\text { Patin siam } x \text { patin nasutus } \\
\text { P. hypophthalmus } x \text { P. nasutus }\end{array}$ & $81.01-95.85$ & $86.64 \pm 5.32^{a}$ & 28.32 \\
\hline \multirow{5}{*}{$\begin{array}{c}\text { Derajat } \\
\text { deformit as larva } \\
\text { Larval } \\
\text { deformity rate } \\
\text { (\%) }\end{array}$} & $\begin{array}{l}\text { Patin siam } \\
\text { P. hypophthalmus }\end{array}$ & $0.00-7.08$ & $3.50 \pm 2.39^{a}$ & - \\
\hline & $\begin{array}{l}\text { Patin jambal } \\
\text { P. djambal }\end{array}$ & $20.69-40.00$ & $32.04 \pm 7.58^{\mathrm{b}}$ & - \\
\hline & $\begin{array}{l}\text { Patin nasutus } \\
\text { P. nasutus }\end{array}$ & $7.41-57.63$ & $28.66 \pm 19.12^{\mathrm{b}}$ & - \\
\hline & $\begin{array}{c}\text { Patin siam } x \text { patin jambal } \\
\text { P. hypophthalmus } x \text { P. djambal }\end{array}$ & $0.81-5.81$ & $3.30 \pm 1.75^{\mathrm{a}}$ & 81.43 \\
\hline & $\begin{array}{l}\text { Patin siam } \times \text { patin nasutus } \\
\text { P. hypophthalmus } \times \text { P. nasutus }\end{array}$ & $0.00-4.67$ & $2.72 \pm 1.71^{\mathrm{a}}$ & 83.08 \\
\hline
\end{tabular}

Keterangan (Note):

Huruf superscript yang berbeda pada parameter dan kolom yang sama menunjukkan berbeda nyata $(\mathrm{P}<0,05)($ Different superscript letters in the same parameter and column represent significantly differences $(P<0.05))$

nya sebesar $28,32 \%$ ) daripada yang difertilisasi dengan sperma ikan patin jambal (dengan heterosis terhadap rata-rata kedua induk tetuanya sebesar 17,28\%). Hal tersebut mengindikasikan bahwa sperma ikan patin nasutus cenderung memiliki kualitas yang relatif lebih bagus daripada sperma patin jambal. Selanjutnya, telur ikan patin nasutus dan jambal yang difertilisasi dengan masing-masing sperma ikan patin nasutus dan jambal mengha- 
silkan derajat penetasan yang lebih rendah, mengindikasikan bahwa telur ikan patin nasutus dan jambal yang digunakan dalam penelitian ini memiliki kualitas yang lebih rendah daripada telur ikan patin siam. Hasil evaluasi derajat penetasan tersebut mengindikasikan bahwa sperma patin nasutus potensial untuk digunakan dalam hibridisasi dengan telur patin siam dengan tingkat produktivitas yang relatif lebih tinggi daripada menggunakan sperma patin jambal.

Derajat penetasan pada hibridisasi ikanikan Siluriformes juga menunjukkan adanya variasi. Derajat penetasan yang tinggi mengindikasikan bahwa hibridisasi tersebut potensial untuk dikembangkan karena tingkat produktivitasnya tinggi. Contoh hibridisasi yang menghasilkan derajat penetasan relatif tinggi dan potensial antara lain adalah hibridisasi antara betina ikan lele $C$. batrachus dengan jantan C. gariepinus (Rahman et al., 1995; Sahoo et al., 2003) dan hibridisasi antara betina ikan lele $C$. meladerma dengan jantan C. gariepinus (Lenormand et al., 1999). Hibridisasi antara ikan lele C. macrocephalus dengan patin siam (Tarnchalanukit, 1986; NaNakorn et al., 1993) dan hibridisasi antara betina ikan M. gulio dengan jantan M. montanus (Haniffa et al., 2009) dilaporkan menghasilkan derajat penetasan yang rendah dan tidak potensial untuk dikembangkan.

Derajat deformitas larva hasil penetasan telur patin siam yang difertilisasi dengan sperma patin nasutus menunjukkan nilai yang terendah, tetapi tidak berbeda nyata $(P>0,05)$ dengan derajat deformitas larva patin siam dan patin hibrida siam $\times$ jambal, sedangkan derajat deformitas larva ikan patin jambal dan nasutus menunjukkan nilai yang tertinggi $(P<0,05)$. Tingginya derajat deformitas larva ikan patin jambal dan nasutus merupakan hal yang relatif sering terjadi dalam kegiatankegiatan pemijahan ikan patin di Sukamandi (pengamatan pribadi, data tidak dipublikasikan). Larva-larva yang mengalami deformitas tersebut diduga merupakan hasil dari telurtelur yang pada saat proses pengurutan (stripping) telah mengalami tahap kematangan berlebih (overipe), sebagaimana dilaporkan oleh Legendre et al. (2000b) pada ikan patin siam. Hal tersebut mengindikasikan relatif rendahnya kualitas telur. Dalam proses pemilihan induk-induk yang akan dipijahkan, relatif sulit untuk mendapatkan induk-induk betina ikan patin jambal dan nasutus yang te- lur intraovariannya memiliki tahap perkembangan telur yang seragam, sehingga pada saat proses pengurutan dalam pengambilan telur, kondisi tersebut tampaknya menyebabkan telur hasil pengurutan juga memiliki tingkat kematangan yang relatif tidak seragam, dengan sebagian telur telah mengalami tahap kematangan berlebih.

Hasil evaluasi derajat deformitas larva tersebut menunjukkan bahwa hibridisasi dengan menggunakan telur ikan patin siam dan sperma ikan patin jambal (dengan heterosis terhadap rata-rata kedua induk tetuanya sebesar $81,43 \%$ ) dan sperma patin nasutus (dengan heterosis terhadap rata-rata kedua induk tetuanya sebesar $83,08 \%$ ) potensial untuk dilakukan, karena derajat deformitas larva yang dihasilkan tidak berbeda dari derajat deformitas larva ikan patin siam. Rendahnya derajat deformitas larva ikan patin hibrida siam $\times$ jambal dan patin hibrida siam $x$ nasutus tersebut juga mengindikasikan bahwa tingkat produktivitasnya tinggi dan mendukung dalam upaya produksi massal benihnya, sehingga potensial untuk dikembangkan.

Derajat deformitas larva ikan-ikan Siluriformes hibrida juga menunjukkan adanya variasi. Derajat deformitas larva yang tinggi mengindikasikan bahwa tingkat produktivitas hibridisasi tersebut rendah sehingga tidak potensial untuk dikembangkan, karena larvalarva yang menetas dengan kondisi abnormal tersebut umumnya tidak dapat bertahan hidup selama proses pemeliharaan larva. Hibridisasi secara resiprokal antara ikan lele C. gariepinus dengan $H$. longifilis (Legendre et al., 1992), hibridisasi antara betina ikan lele $C$. batrachus dengan jantan C. gariepinus (Rahman et al., 1995) dan hibridisasi antara betina ikan lele $C$. meladerma dengan jantan C. gariepinus (Lenormand et al., 1999) dilaporkan menghasilkan derajat deformitas larva yang relatif rendah dan tidak berbeda dari induk-induk tetuanya, mengindikasikan bahwa hibrida-hibrida tersebut potensial untuk dikembangkan. Sebaliknya, hasil penelitian Haniffa et al. (2009) menunjukkan bahwa hibridisasi antara betina ikan $M$. gulio dengan jantan M. montanus tidak potensial untuk dikembangkan, karena derajat deformitas larvanya lebih tinggi daripada induk tetuanya.

Hasil evaluasi derajat fertilisasi, penetasan, dan deformitas larva pada penelitian ini secara umum mengindikasikan bahwa sperma ikan patin nasutus cenderung memiliki kualitas 

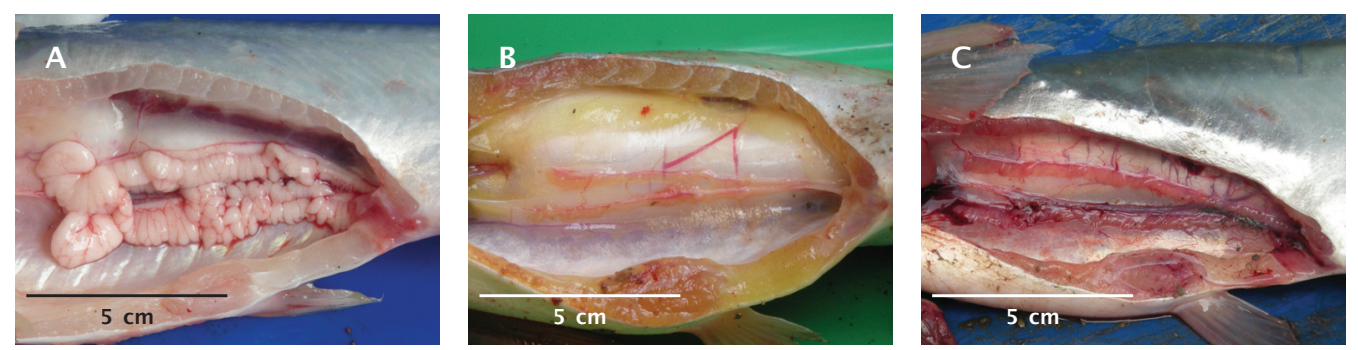

Gambar 2. Testis ikan patin nasutus umur delapan bulan yang telah berada pada tingkat matang (A) dibandingkan dengan testis ikan patin siam (B) dan ikan patin jambal (C) umur delapan bulan yang masih berada pada tingkat muda

Figure 2. Testes of eight months old $P$. nasutus which attained the mature stage $(A)$ compared to that of $\boldsymbol{P}$. hypophthalmus (B) and P. djambal (C) which were still at the immature stages

yang lebih bagus daripada sperma ikan patin jambal maupun patin siam. Hal tersebut tampaknya bersesuaian dengan keragaan organ reproduksi jantan ikan patin siam, jambal, dan nasutus. Hasil pengamatan organ reproduksi yang dilakukan pada sampel ikan patin siam, jambal, dan nasutus yang berumur delapan bulan (bobot berkisar 324,35-467,73 g) menunjukkan bahwa jantan ikan patin nasutus pada umur tersebut telah memiliki testis tingkat matang, meskipun masih berukuran relatif kecil, secara morfologis ditandai dengan testis yang telah berwarna putih, tampak mengandung cairan sperma (Gambar 2A). Pada umur tersebut, testis jantan ikan patin siam masih berada pada tingkat muda, berukuran sangat kecil, berwarna transparan-kemerahan (Gambar 2B). Demikian pula, testis jantan patin jambal pada umur tersebut masih berada pada tingkat muda dengan morfologi testis yang serupa dengan morfologi testis patin siam (Gambar 2C). Hasil pengamatan tersebut menunjukkan bahwa kematangan gonad jantan patin nasutus terjadi lebih dahulu daripada jantan ikan patin siam dan jambal, dan setidaknya telah dapat tercapai pada umur delapan bulan, sedangkan jantan ikan patin siam dan ikan patin jambal pada umur tersebut masih berada pada tingkat muda. Jantan patin siam dilaporkan dapat mencapai tingkat matang gonad pada umur 10 bulan, sedangkan pada jantan patin jambal tercapai pada umur 12 tahun (Legendre et al., 1999a; 2000a).

\section{KESIMPULAN}

Derajat fertilisasi dan penetasan ikan patin hibrida siam $x$ nasutus dan patin hibrida siam $x$ jambal menunjukkan nilai yang tinggi dan tidak berbeda nyata dengan ikan patin siam, sedangkan ikan patin jambal dan nasutus memiliki derajat fertilisasi dan penetasan yang lebih rendah. Derajat deformitas larva patin hibrida siam $x$ nasutus dan patin hibrida siam $x$ jambal menunjukkan nilai yang rendah dan tidak berbeda nyata dengan ikan patin siam, sedangkan larva ikan patin jambal dan nasutus memiliki derajat deformitas larva yang lebih tinggi. Tingkat produktivitas ikan patin hibrida siam $x$ nasutus dan patin hibrida siam $x$ jambal sangat tinggi dan mendukung dalam upaya produksi massal benihnya.

\section{UCAPAN TERIMA KASIH}

Penulis menyampaikan terima kasih dan penghargaan yang sebesar-besarnya kepada Ika Nurlaela dan Kamlawi, serta seluruh pembantu peneliti komoditas penelitian ikan patin atas bantuan teknisnya selama kegiatan seleksi induk dan pemijahan buatan.

\section{DAFTAR ACUAN}

Ariyanto, D. \& Utami, R. 2004. Evaluasi laju pertumbuhan, keragaman genetik, dan estimasi heterosis pada persilangan antar spesies ikan patin (Pangasius sp.). Jurnal Perikanan (Journal of Fisheries Sciences), VIII(1): 81-86.

Ataguba, G.A., Annune, P.A., \& Ogbe, F.G. 2009. Induced breeding and early growth of progeny from crosses between two African clariid fishes, Clarias gariepinus (Burchell) and Heterobranchus longifilis under hatchery conditions. Journal of Applied Biosciences, 14: 755-760.

Bartley, D.M., Rana, K., \& Immink, A.J. 2001. The 
use of inter-specific hybrids in aquaculture and fisheries. Reviews in Fish Biology and Fisheries, 10: 325-337.

Binh, T.V. 2006. Before and after the catfish war: market analysis. CAS Discussion Paper No. 50. Centre for ASEAN Studies. 26 pp.

Cacot, P. 1999. Description of the sexual cycle related to the environment and set up of the artificial propagation in Pangasius bocourti (Sauvage, 1880) and Pangasius hypophthalmus (Sauvage, 1878) reared in floating cages and ponds in the Mekong Delta. In Legendre, M. \& Parisele, A. (Eds.), The biological diversity and aquaculture of Clariid and Pangasiid catfishes in SouthEast Asia. Proceeding of The Mid-Term Workshop of the Catfish Asia Project, 11-15 May 1998. Cantho. Vietnam, p. 71-89.

Cacot, P., Eeckhoutte, P., Muan, D.T., Nguyen, V.T., Legendre, M., Mariojouls, C., \& Lazard, J. 2003. Induced spermiation and milt management in Pangasius bocourti (Sauvage, 1880). Aquaculture, 21 5: 67-77.

Cacot, P., Legendre, M., Dan, T.Q., Tung, L.T., Liem, P.T., Mariojouls, C., \& Lazard, J. 2002. Induced ovulation of Pangasius bocourti (Sauvage, 1880) with a progressive hCG treatment. Aquaculture, 213: 199-206.

Campet, M., Cacot, P., Lazard, J., Dan, T.Q., Muon, D.T., \& Liem, P.T. 1999. Egg quality of an Asian catfish of the Mekong River (Pangasius hypophthalmus) during the process of maturation induced by hCG injections. In Legendre, M. \& Parisele, A. (Eds.), The biological diversity and aquaculture of Clariid and Pangasiid catfishes in South-East Asia. Proceeding of The MidTerm Workshop of the Catfish Asia Project, 11-15 May 1998. Cantho. Vietnam, p. 113116.

Chevassus, B. 1983. Hybridization in fish. Aquaculture, 33: 245-262.

Fuiman, L.A. 2002. Special consideration of fish eggs and larvae. In Fuiman, L.A. \& Werner, R.G. (Eds.), Fishery science: The unique contributions of early life stages. Blackwell Publishing Company. Oxford, p. 1-32.

Gustiano, R. 2004. Biometric analysis of the artificial hybridization between Pangasius djambal Bleeker, 1846 and Pangasianodon hypophthalmus Sauvage, 1878. Indonesian Journal of Agricultural Science, 5(2): 70-74.

Gustiano, R. 2009. Pangasiid catfishes of Indo- nesia. Buletin Plasma Nutfah, 15(2): 91 100.

Gustiano, R. \& Kristanto, A.H. 2007. Evaluation of hybridization between Pangasius djambal Bleeker, 1846 and Pangasianodon hypophthlamus (Sauvage, 1878): biometric characterization and growth analysis. Indonesian Aquaculture Journal, 2(1): 2733.

Haniffa, M.A., Dhanaraj, M., Ramakrishnan, C.M., Manju, R.A., Kumar, Y.A., \& Singh, S.V.A. 2009. Hybridization between threatened freshwater catfish Mystus gulio (Hamilton \& Buchanan) and Mystus montanus (Jerdon) by artificial fertilization. Indian Journal of Experimental Biology, 47: 679-683.

Hardjamulia, A., Djajadiredja, R., Atmawinata, S., \& Idris, D. 1981. Pembenihan jambal siam (Pangasius sutchi) dengan suntikan ekstrak kelenjar hipofisa ikan mas (Cyprinus carpio). Buletin Penelitian Perikanan, I(2): 183-190.

Jalabert, B. 2008. An overview of 30 years international research in some selected fields of the reproductive physiology of fish. Cybium, 32(2): 7-13.

Khan, M.H.K. \& Mollah, M.F.A. 2004. Further trials on induced breeding of Pangasius pangasius (Hamilton) in Bangladesh. Asian Fisheries Science, 17: 135-146.

Kementerian Kelautan dan Perikanan [KKP]. 2010. Rencana strategis Kementerian Kelautan dan Perikanan 2010-2014. Kementerian Kelautan dan Perikanan Republik Indonesia. Jakarta, $84 \mathrm{hlm}$.

Legendre, M. 2008. Characterisation, utilization and maintenance of biological diversity for the diversification and sustainability of catfish culture in South-East Asia. In Santos, E.N. \& Nauen, C.E. (Eds.), Catalogue of Synopses of International S \& T Cooperative (INCO) Projects on Challenges in Fisheries, Coastal Zones, Wetlands and Aquaculture. ACP-EU Fisheries Resources Report 17, p. 206-207.

Legendre, M., Cosson, J., \& Subagja, J. 2008. Sperm characteristics and motility in Pangasianodon hypophthalmus (Sauvage, 1878) and Pangasius djambal Bleeker, 1846 (Pangasiidae, Siluriformes). Cybium, 32(2): 183-184.

Legendre, M., Pouyaud, L., Slembrouck, J., Gustiano, R., Kristanto, A.H., Subagja, J., Komarudin, O., Sudarto, \& Maskur. 2000a. Pangasius djambal: a new candidate species for fish culture in Indonesia. Indone- 
sian Agricultural Research and Development Journal, 22(1): 1-14.

Legendre, M., Slembrouck, J., \& Subagja, J. 1999a. First result on growth and artificial propagation of Pangasius djambal (Siluriformes, Pangasiidae) in Indonesia. In Legendre, M. \& Parisele, A. (Eds.), The biological diversity and aquaculture of Clariid and Pangasiid catfishes in South-East Asia. Proceeding of The Mid-Term Workshop of the Catfish Asia Project, 11-15 May 1998. Cantho. Vietnam, p. 97-102.

Legendre, M., Slembrouck, J., Subagja, J., \& Kristanto, A.H. 1999b. Effect of varying latency period on the in vivo survival of ova after Ovaprim- and hCG-induced ovulation in the Asian catfish Pangasius hypophthalmus (Pangasiidae, Siluriformes). In Legendre, M. \& Parisele, A. (Eds.), The biological diversity and Aquaculture of Clariid and Pangasiid Catfishes in SouthEast Asia. Proceeding of The Mid-Term Workshop of the Catfish Asia Project, 11-15 May 1998. Cantho. Vietnam, p. 119-125.

Legendre, M., Slembrouck, J., Subagja, J., \& Kristanto, A.H. 2000b. Ovulation rate, latency period and ova viability after $\mathrm{GnRH}$ or hCG-induced breeding in the Asian catfish Pangasius hypophthalmus (Siluriformes, Pangasiidae). Aquatic Living Resources, 13: 145-151.

Legendre, M., Subagja, J., \& Slembrouck, J. 1999c. Absence of marked seasonal variations in sexual maturity of Pangasius hypophthalmus brooders held in Sukamandi Station (Java, Indonesia). In Legendre, M. \& Parisele, A. (Eds.), The biological diversity and aquaculture of Clariid and Pangasiid catfishes in South-East Asia. Proceeding of The Mid-Term Workshop of the Catfish Asia Project, 11-15 May 1998. Cantho. Vietnam, p. 91-96.

Legendre, M., Teugels, G.G., Cauty, C., \& Jalabert, B. 1992. A comparative study on morphology, growth rate and reproduction of Clarias gariepinus (Burchell, 1822), Heterobranchus longifilis Valenciennes, 1840 , and their reciprocal hybrids (Pisces, Clariidae). Journal of Fish Biology, 40: 5979.

Lenormand, S., Slembrouck, J., Pouyaud, L., Subagja, J., \& Legendre, M. 1999. Evaluation of hybridisation in five Clarias species (Siluriformes, Clariidae) of African (C. gariepinus) and Asian origin (C. batrachus,
C. meladerma, C. nieuhofii, and C. teijsmanni). In Legendre, M. \& Parisele, A. (Eds.), The biological diversity and aquaculture of Clariid and Pangasiid catfishes in South-East Asia. Proceeding of The MidTerm Workshop of the Catfish Asia Project, 1 1-15 May 1998. Cantho. Vietnam, p. 195209.

Lutz, C.G. 2001. Practical genetics for aquaculture. Fishing News Book. London, 252 pp.

Na-Nakorn, U., Sidthikraiwong, P., Tarnchalanukit, W., \& Roberts, T.R. 1993. Chromosome study of hybrid and gynogenetic offspring of artificial crosses between members of catfish families Clariidae and Pangasiidae. Environmental Biology of Fishes, 37: 317-322.

$\mathrm{Ng}$, H.H. \& Kottelat, M. 2008. The identity of Clarias batrachus (Linnaeus, 1758), with the designation of a neotype (Teleostei: Clariidae). Zoological Journal of the Linnean Society, 153: 725-732.

Pouyaud, L., Teugels, G.G., \& Legendre, M. 1999. Description of a new pangasiid catfish from South-East Asia (Siluriformes). Cybium, 23(3): 247-258.

Rahman, M.A., Bhadra, A., Begum, N., Islam, M.S., \& Hussain, M.G. 1995. Production of hybrid vigor trough crossbreeding between Clarias batrachus Lin. and Clarias gariepinus Bur. Aquaculture, 138: 125-130.

Sadili, D. 1999. Marketing of pangasiid catfishes in Java and Sumatera, Indonesia. In Legendre, M. \& Parisele, A. (Eds.), The biological diversity and aquaculture of Clariid and Pangasiid catfishes in South-East Asia. Proceeding of The Mid-Term Workshop of the Catfish Asia Project, 11-15 May 1998. Cantho. Vietnam, p. 21-26.

Sahoo, S.K., Giri, S.S., Sahu, A.K., \& Ayyappan, S. 2003. Experimental hybridization between catfish Clarias batrachus (Linn.) $\mathrm{x}$ Clarias gariepinus (Bur.) and performance of the offspring in rearing operations. Asian Fisheries Science, 16: 157-166.

Sudarto. 1999. Karakterisasi genetik dan zooteknik ikan lele (Clariidae) dan patin (Pangasiidae) dari wilayah Asia Tenggara. Makalah dalam: Hardjamulia, A., Sumantadinata, K., Sugama, K., Sudradjat, A., \& Heruwati, E.S. (Eds.), Prosiding Seminar Hasil Penelitian Genetika Ikan. Jakarta, 8 Februari 1999. hlm. 26-29.

Tahapari, E., Iswanto, B., \& Sularto. 2011. 
Keragaan reproduksi ikan patin nasutus (Pangasius nasutus Bleeker, 1863) sebagai kandidat ikan budidaya. J. Ris. Akuakultur, 6(1): 17-30.

Tarnchalanukit, W. 1986. Experimental hybridization between catfishes families Clariidae and Pangasiidae in Thailand. Environmental Biology of Fishes, 16(4): 317-320.

Xuan, L.N. \& Liem, P.T. 1999. Preliminary results on the induced spawning of two catfish species, Pangasius conchophilus and Pangasius sp. in the Mekong Delta, Vietnam. In Legendre, M. \& Parisele, A. (Eds.), The biological diversity and aquaculture of Clariid and Pangasiid catfishes in SouthEast Asia. Proceeding of The Mid-Term Workshop of the Catfish Asia Project, 1 1-15 May 1998. Cantho. Vietnam, p. 103-106. 